\title{
Coping with a Money Crunch: Family Cooperation ${ }^{1}$
}

\author{
Contact Author: Martie Gillen, PhD²
}

It's easy to say that financial problems, such as losing your job, should be shared with your family. But it's hard to know just how to do that. One method of bringing the family together with a feeling of team spirit is a family council meeting. This is a simple strategy for bringing a harmonious pattern into the family routine.

The main benefit of the family council meeting is that matters of common family interest can be discussed. Each family member has rights, responsibilities, and privileges, but must also function in certain matters as a single unit. Information about the family financial problems are collected and shared, providing family members a floor to voice concerns and suggestions. The existence of the group and the rights of everyone in it are safeguarded. The members of the family get a feeling of security from this unity. This is an opportunity to make positive money message memories for your children.

\section{Family Council Guidelines}

The benefits from a family council meeting will depend on everyone working together. Here are some suggestions for success:

- Give each family member an opportunity to speak freely and with the assurance that what is said will be treated in confidence and with respect.

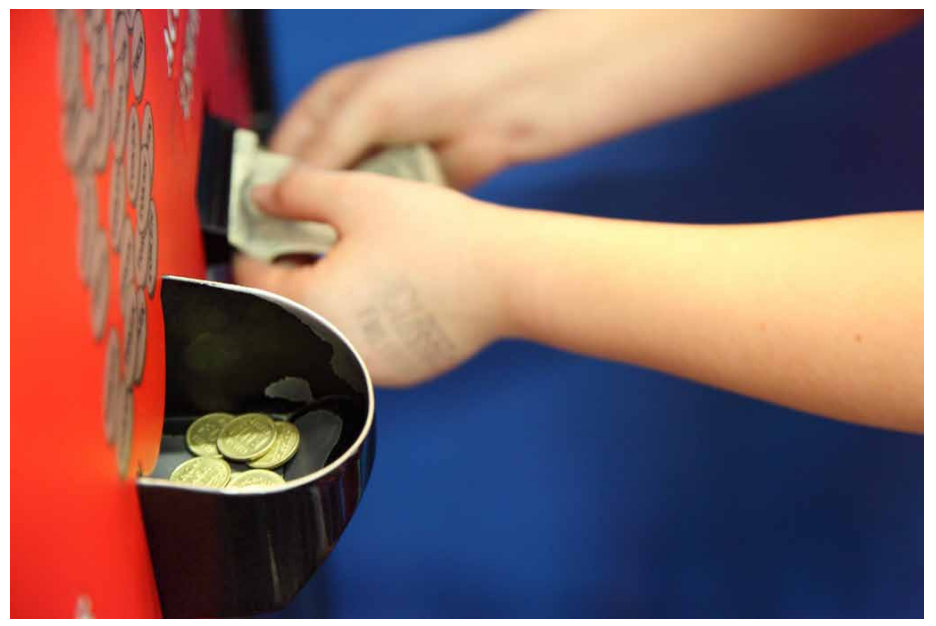

Figure 1. Child Putting Money in Arcade Token Change Machine Credits: D. Sharon Pruitt (CC BY 2.0) http://flic.kr/p/99qLaL

- Each member should have an opportunity to tell his/her side of the story. This is one good way to find out the real causes underlying problems which may seem unimportant on the surface.

- Sometimes a family agreement cannot be reached easily when hard problems arise. If so, any plan or solution should be tried on a trial basis, and changed if the results show it doesn't work.

- During the discussion, the attitude of Dad and Mom is an important factor in making the council a success. Focus on problem solving, not on criticism or blame. Children

1. This document is FCS7005, one of a series of the Department of Family, Youth and Community Sciences, Florida Cooperative Extension Service, Institute of Food and Agricultural Sciences, University of Florida. Original publication date November 1, 1984. Revised December 2005, December 2012. Visit the EDIS website at http://edis.ifas.ufl.edu.

2. Contact author for this publication is Martie Gillen, assistant professor. Written in 1984 by Katey Walker, former UF/IFAS Family Resource Management specialist; first revised in 2005 by Mary N. Harrison (deceased), former professor and Consumer Education specialist; last revised in 2012 by Martie Gillen, assistant professor and Family and Consumer Economics for Older Adults specialist; Department of Family, Youth and Community Sciences, Institute of Food and Agricultural Sciences, University of Florida, Gainesville, FL 32611. 
learn by having a chance to take part, and their opinions should be respected.

- In money matters, the family council can make group decisions based on everyone's input. The group decisions will be more likely to have the cooperation and support of the whole family. The mechanics of the council are not as important as the spirit behind the idea.

\section{Evaluate the Ways Your Family Uses Money}

Many people buy things, not because they need them, but because they want to spend money to satisfy their emotions. Emotions impact our financial decisions. Self-esteem is closely linked to emotions and can have an impact on our spending habits and our financial decisions as well. For example, if we feel like something is missing from our lives, or that we don't measure up to the expectations of ourselves or others, we might buy something to prove ourselves or to fill the void, at least temporarily. Now, more than ever, it's time to tighten the purse strings and abandon self-defeating spending habits. Do you see yourself and your family in any of the following examples?

- Do you feel you deserve to buy something for yourself just because someone else gets something new or because you have had a difficult day?

- Do you buy things you don't really need now because you think "tomorrow it may cost even more" or "we might be even less able to afford it later"?

- Do you use money to bribe or reward others? Or do you withhold money as a punishment?

- Do you spend money as a way to work off stress or to relieve boredom or anxiety?

If you answer YES to any of these questions, you have found some guidelines on where to begin to change your spending habits. This can change a conflict-ridden family into a cooperative one.

To change spending habits when your income has dropped, you must evaluate your spending habits. It helps to tackle one problem area at a time. For example, during one family council meeting, focus on ways to have family fun without money. At another session, tackle methods for record keeping. Keeping good records helps you keep track of your money and control spending. At still another, discuss where it will be easiest to spend less. Talk about cleaning supplies, food, clothing, utilities, cell phone services, television services such as cable, recreation, driving, and insurance. (While some insurance "frills" can be easily dropped, don't tamper with basic coverage during this period when you are economically vulnerable.)

Before any item or service is purchased, ask:

- Can I do without it?

- Can I postpone it?

- Can I substitute something less expensive?

- Can I shop around for a better deal?

- Can I make or do it myself?

\section{Make Decisions Together}

Success in decision making comes from sharing the united efforts of a family that works together to understand its own needs and respects the needs of others. Children who are included in family decisions usually welcome the opportunity to figure out how they can contribute to the family's support during the crisis period. Children can take part in a family council meeting at a young age. For example, a four-year-old can decide to help turn the lights off or prioritize recreation choices.

The chance to explain how family choices are affecting them and to feel that their needs will be considered in future decisions gives both parents and children feelings of security and belonging. This helps everyone feel that they are important members of the family and that other people care about them. At times of stress during a money crunch, this feeling of belonging and cooperating as a team is very helpful. 